\title{
Uji Degradabilitas Pakan Komplit yang Mengandung Daun Chromolaena odorata secara In- Vitro
}

\section{Degradability Test Complete Feed which Contains Chromolaena odorata Leaves with In-vitro}

\author{
Firsoni ${ }^{1}$ dan R. Yunita ${ }^{2}$ \\ ${ }^{1)}$ Badan Tenaga Nuklir Nasional, ${ }^{2)}$ STIPER, Sijunjung \\ e-Mail : firsoni@batan.go.id; yunitaria9191@yahoo.co.id \\ (Diterima: 15 November 2013; Disetujui: 08 Mei 2014)
}

\begin{abstract}
ABSTRAK
Penelitian ini bertujuan untuk mengetahui pengaruh daun Chromolaena odorata di dalam pakan komplit terhadap degradabilitas dan produksi biomassa mikroba. Metode penelitian memakai Rancangan Acak Kelompok dengan 3 perlakuan dan 5 kelompok. Perlakuan yang diuji adalah $\mathrm{A}=$ rumput lapang (RL) $40 \%$ + jerami padi fermentasi (JPF) $20 \%$ + konsentrat pasar (KP) 40\%; B = RL 40\% + JPF 20\% + KP $20+$ Chromolaena odorata (CR) $20 \%$ dan C= RL $40 \%+$ JPF $20 \%+\mathrm{CR} 40 \%$. Sampel ditimbang $500 \pm 5 \mathrm{mg}$, dimasukkan ke dalam syringe glass $100 \mathrm{ml}$ ditambahkan $50 \mathrm{ml}$ media campuran cairan rumen dengan buffer bicarbonat dan diinkubasi pada suhu 390C selama 48 jam. Parameter yang diukur meliputi produksi gas, degradasi bahan kering (DBK) dan organik (DBO), serta biomassa mikroba cairan rumen setelah inkubasi 48 jam. Hasil penelitian menunjukkan perlakuan berpengaruh nyata $(\mathrm{P}<0,05)$ terhadap penurunan produksi gas, peningkatan degradabilitas bahan kering dan organik, dan peningkatan biomassa mikroba setelah pemakaian Chromolaena odorata. Nilai produksi gas tertinggi terjadi pada perlakuan A $(71,49 \mathrm{ml})$ dan terendah perlakuan C $(60,33 \mathrm{ml})$. Degradabilitas bahan kering dan organik tertinggi dihasilkan perlakuan $\mathrm{C}(64,13$ dan $64,34 \%)$, sementara yang terendah perlakuan A $(61,38$ dan $61,64 \%)$. Biomassa mikroba diperoleh dari setiap perlakuan yaitu C (123,34 mg), B $(114,21 \mathrm{mg})$ dan A $(104,18 \mathrm{mg})$. Effisiensi pembentukan biomassa mikroba tertinggi dihasilkan perlakuan C $(71,09 \%)$ dan terendah pada perlakuan A $(64,35 \%)$.
\end{abstract}

Kata kunci : Chromolaena odorata, pakan komplit, in-vitro, biomassa mikroba

\begin{abstract}
In-vitro test on the degradability of complete feed was done to evaluate the effect of Chromolaena odorata leaves and microbe biomass production. The research used randomized block design with 3 treatments and 7 blocks as repetition. The treatments were $A=$ field grass $(R L)$ $40 \%+$ fermented rice straw $(J P F) 20 \%+$ common concentrate $(K P) 40 \% ; B=R L 40 \%+J P F$ $20 \%+K P 20+$ Chromolaena odorata (CR) $20 \%$ and $C=R L 40 \%+J P F 20 \%+C R 40 \%$. Samples were weighted $500 \pm 5 \mathrm{mg}$, put into $100 \mathrm{ml}$ glass syringe, added by $40 \mathrm{ml}$ media rumen liquid with buffer bicarbonate and incubated on 390C for 48 hours. Parameters consisted of gas production, dry and organic matter degradability, and microbes biomass production for 48 hours incubation. The results showed that the treatments significantly $(P<0.05)$ affect the reduction of gas production, the rise of dry and organic matter degradability as well as microbes biomass after addition of Chromolaena odorata. The highest gas was achieved on treatment A $(71.49 \mathrm{ml})$ and in contrast the lowest gas was on $C(60.33 \mathrm{ml})$. The highest degradability of dry and organic matter was on $C$ (64.13 and $64.34 \%)$, the lowest was on $A(61.38$ and $61.64 \%)$. Microbial biomass were obtained at each treatment $C(123.34 \mathrm{mg}), B(114.21 \mathrm{mg})$ and $A(104.18 \mathrm{mg})$. While the highest production of microbial efficiency was obtained at treatment C (71.09\% BOT), in fact the lowest production was at $A(64.35 \%)$.
\end{abstract}

Keywords: Chromolaena odorata, complete feed, in-vitro, microbial biomass 


\section{PENDAHULUAN}

Salah satu faktor yang sangat menentukan keberhasilan pengembangan usaha peternakan adalah ketersediaan pakan yang mempunyai nilai nutrisi sesuai yang dibutuhkan oleh ternak ruminansia. Musim kemarau menyebabkan ketersediaan rumput segar untuk pakan ternak menjadi rendah, selain itu kandungan serat kasar yang cukup tinggi serta protein kasar yang rendah mengurangi kualitas rumput pada daerah tropis. Kondisi ini menyebabkan produktifitas ternak ruminansia masih saja rendah.

Peningkatan kualitas pakan terutama untuk memenuhi kebutuhan protein di dalam pakan sangat dibutuhkan untuk meningkatkan produksi ternak ruminansia. Keseimbangan ketersediaan karbohidrat dan protein sangat dibutuhkan untuk sintesis protein mikroba, yang merupakan sumber pakan utama ternak ruminansia (Ørskov, 1988). Pemanfaatan sumber protein dan karbohidrat yang mudah diperoleh di sekitar peternak akan mengurangi biaya pakan, sehingga dapat meningkatkan keuntungan bagi peternak. Salah satu cara untuk mengatasi kekurangan protein adalah dengan memanfaatkan daun kirinyuh atau semak bunga putih (Chromolaena odorata), untuk memenuhi kebutuhan karbohidrat seperti biasa diperoleh dari rumput lapang, jerami padi atau dedak.

Chromolaena odorata sangat banyak tumbuh liar di seluruh wilayah Indonesia. Gulma ini diperkirakan sudah tersebar di Indonesia sejak tahun 1910-an, namun keberadaannya kurang mendapat perhatian, kecuali oleh kalangan perkebunan karet, karena selain merupakan gulma di padang rumput, Kirinyuh juga merupakan gulma yang sangat merugikan perkebunan karet (Sipayung et al., 1991). Chromolaena odorata mengandung protein yang tinggi (21-36\%) setara dengan turi, lamtoro dan gamal, palatabilitas lebih baik dari gamal (Marten, 2007) dan penelitian di Afrika dan Eropa menunjukkan adanya senyawa anti helmintik/obat anti cacing.

Namun demikian pemanfaatan gulma ini perlu dikaji lebih jauh karena memiliki zat anti nutrisi. Sesuai pernyataan Ikhimioya (2003), Chromolaena odorata mengandung Haemagglutinnin $9.72 \mathrm{mg} / \mathrm{g}$, Oxalate $1.89 \%$, Phytic acid $1.34 \%$ dan Saponin $0.50 \%$. Kirinyuh tergolong ke dalam gulma yang beracun dan berkayu karena kandungan nitratnya yang sangat tinggi (Ginting et al., 1981). Namun untuk menghilangkan racunnya dapat diberikan kepada ternak dalam bentuk pakan lengkap yang terlebih dahulu dijadikan tepung (Ginting et al., 1981).

Berdasarkan hal diatas, maka dilakukan penelitian untuk mengetahui pengaruh Chromolaena odorata sebagai sumber protein di dalam pakan lengkap terhadap produksi gas dan degradabilatas secara in - vitro.

\section{METODE}

Bahan pakan yang dipakai di dalam penelitian ini adalah daun Chromolaena odorata yang diperoleh dari Cipanas Kabupaten Bogor, jerami padi yang telah difermentasi, rumput lapangan, konsentrat pasar. Jerami padi fermentasi dibuat dengan fermentasi menggunakan starter khusus yang sudah dicampur ragi selama 19 hari (Andini, et al., 2011). Sampel rumput, jerami padi fermentasi dan Chromolaena odorata yang sudah dikeringkan di dalam oven $55^{\circ} \mathrm{C}$ selama 3-8 hari, kemudian di giling dan diayak halus. Setelah semua sampel halus, ditimbang sesuai persentase perlakuan yang telah ditetapkan sejak awal dan kemudian di campur merata (homogen) sesuai dengan masing-masing perlakuan.

Perlakuan yang diuji yaitu :

$\mathrm{A}=$ rumput lapang $(\mathrm{RL}) 40 \%+$ jerami padi fermentasi (JPF) 20\% + konsentrat pasar (KP) $40 \%$;

$\mathrm{B}=\mathrm{RL} 40 \%+\mathrm{JPF} 20 \%+\mathrm{KP} 20+$ Chromolaena odorata (CR) 20\% dan

$\mathrm{C}=\mathrm{RL} 40 \%+\mathrm{JPF} 20 \%+\mathrm{CR} 40 \%$. Peralatan yang digunakan adalah waterbath, beaker glass, kain kasa, corong plastik, syringe glass ukuran $100 \mathrm{ml}, \mathrm{pH}$ meter digital, oven $105^{\circ} \mathrm{C}$ dan furnece $500^{\circ} \mathrm{C}$, termometer, neraca digital, cawan Conway, peralatan destilasi dan pemanas. 
Media buffer bicarbonat yang sudah disiapkan di dalam Erlenmeyer $2000 \mathrm{ml}$, ditambahkan larutan reduktor sambil diberi gas $\mathrm{CO}_{2}$ secara kontiniu sampai larutan berubah warna dari biru menjadi pink dan selanjutnya kembali bening, yang menunjukkan media sudah siap untuk dipakai. Cairan rumen diambil segar dari rumen kerbau melalui fistula dimasukkan ke dalam termos yang sudah dipanaskan sebelumnya sesuai suhu rumen, diblender dan disaring dengan kain kasa yang bersih, lalu dimasukkan ke dalam Erlenmeyer 2000 $\mathrm{ml}$ yang sudah diisi dengan media buffer bicarbonat tadi (Khrisnamoorthy, 2001). Media sudah siap untuk dipakai sebagai perlakuan secara in-vitro. Sampel ditimbang 500 \pm 5 $\mathrm{mg}$, dimasukkan ke dalam syringe glass ukuran $100 \mathrm{ml}$, kemudian ditambahkan $40 \mathrm{ml}$ media cairan rumen yang sudah ditambahkan larutan buffer bicarbonat dan diinkubasi didalam waterbath $39,5^{\circ} \mathrm{C}$ selama 48 jam. Variabel yang diukur adalah produksi gas selama inkubasi $0,2,4,6,10,12,24$ dan 48 jam, konsentrasi ammonia dan VFA total di dalam rumen setelah 48 jam inkubasi (Makkar et al., 1995; Blummel et al., 1997).

\section{HASIL DAN PEMBAHASAN}

Hasil analisis sidik ragam menunjukkan bahwa pemakaian konsentrat saja tanpa Chromolaena odorata di dalam pakan lengkap menghasilkan gas yang lebih tinggi (perlakuan A) dibandingkan dengan perlakuan $\mathrm{B}$ dan $\mathrm{C}$ yang mengandung 20 dan $40 \%$ daun Chromolaena odorata. Produksi gas tinggi yang dihasilkan perlakuan A disebabkan oleh kandungan konsentrat yang lebih banyak dibandingkan perlakuan B dan C dimana sebagian konsentrat digantikan Chromolaena odorata untuk meningkatkan kandungan protein pakan komplit. Kandungan protein di dalam pakan mempunyai korelasi positif yang rendah terhadap produksi gas pada inkubasi 48 jam (Getachew, et al, 2004). Produksi gas yang rendah bisa disebabkan oleh terpakainya sebagian bahan organik terfermentasi untuk sintesis mikroba (Ørskov dan Ryle, 1990).

Dari laju produksi gas bisa dilihat terjadi peningkatan produksi gas yang tinggi sampai
24 jam inkubasi, kemudian peningkatannya semakin berkurang sampai 48 jam inkubasi (Gambar 1). Peningkatan produksi gas tertinggi terjadi selama 24 jam inkubasi, selanjutnya terjadi peningkatan yang lebih lambat sampai 48 jam inkubasi (Gambar 1). Tingginya produksi gas selama 24 jam inkubasi disebabkan oleh lebih banyak zat nutrisi yang tercerna kemudian semakin berkurang sampai 96 jam akhirnya menjadi 0 tergantung ketersediaan bahan organik yang bisa dicerna (Ella et al., 1997).

Hasil pengukuran degradabilitas diperoleh pemakaian daun Chromolaena odorata dapat meningkatkan secara nyata $(\mathrm{P}<0,05)$ degradabilitas bahan kering (DBK) dan bahan organik (DBO), biomassa mikroba dan bahan organik yang bisa dicerna. DBK dan DBO tertinggi dihasilkan perlakuan $C$ yaitu 64,13 dan $64,13 \%$, yang terendah perlakuan A yaitu 61,38 dan 61,64\% (Tabel 2). Degradabilitas yang tinggi pada perlakuan $\mathrm{C}$ disebabkan oleh kandungan protein kasar yang lebih tinggi yaitu $15,07 \%$, sehingga ketersediaan protein yang cukup akan dimanfaatkan langsung mikroba rumen untuk sintesis protein mikroba dengan bantuan rangka karbon dari karbohidrat pakan. Menurut Ørskov (1988), bahwa pertumbuhan biomassa mikroba merupakan hasil dari pemanfaatan protein dengan sumber rangka karbon pada pakan oleh mikroba. Degradabilitas pakan bergantung akan kemampuan mikroba untuk mencerna, tergantung pada jenis dan ketersediaan pakan yang dimakan ternak (Czerkawski, 1986).

Protein yang bertambah dengan pemakaian daun Chromolaena odorata bisa langsung dimanfaatkan untuk sintesis protein mikroba, sehingga sekaligus mengurangi produksi gas yang dihasilkan. Hal ini dapat terlihat dari produksi biomassa mikroba tertinggi dihasilkan perlakuan C yaitu 123,34 $\mathrm{mg}$, terendah dihasilkan perlakuan A yaitu $104,18 \mathrm{mg}$. Pertambahan mikroba yang cepat dan banyak meningkatkan kemampuan rumen untuk mencerna serat kasar yang ada pada pakan basal dan sebagian konsentrat. Perlakuan A yang mengandung protein lebih rendah, menghasilkan gas lebih tinggi karena peman 
Tabel 1. Kandungan Nutrisi Pakan Perlakuan.

\begin{tabular}{cccc}
\hline \multirow{2}{*}{ Perlakuan } & BK & BO & PK \\
\cline { 2 - 4 } & & $\%$ & 10,15 \\
A & 86,04 & 89,85 & 12,61 \\
B & 84,76 & 87,39 & 15,07
\end{tabular}

Keterangan: $\mathrm{BK}=$ Bahan kering, $\mathrm{BO}=$ Bahan organik dan $\mathrm{PK}=$ Protein kasar

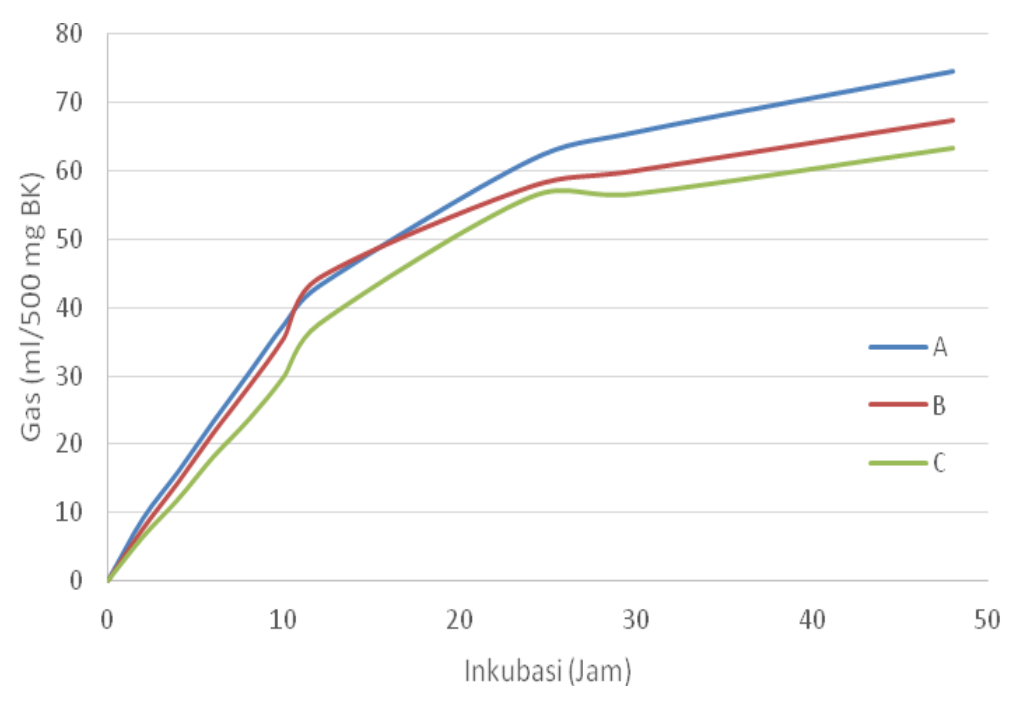

Gambar 1. Laju Produksi Gas 48 Jam Inkubasi

faatan energi yang dihasilkan fermentasi di dalam rumen masih rendah karena keterbatasan protein di dalam pakan. Ransum dengan kandungan serat kasar tinggi menyebabkan kecernaan menjadi rendah (McDonald et al., 2002). Produksi biomassa mikroba berkorellasi positif $(90,25 \%)$ dengan kandungan bahan organik yang mudah dicerna (Gambar 2). Semakin tinggi jumlah bahan organik yang dicerna, maka produksi biomassa mikroba juga semakin tinggi. Kemampuan mikroba untuk mencerna tergantung pada jenis dan ketersediaan bahan pakan yang dimakan ternak (Czerkawski, 1986). Hal ini juga bisa dilihat dari efisiensi produksi biomassa mikroba yang juga semakin meningkat sesuai dengan pertambahan pemakaian daun Chromolaena odorata (Tabel 2).

Hasil pengukuran kandungan amonia menunjukkan tidak berbeda nyata diantara perlakuan $(\mathrm{P}>0,05)$, tetapi terlihat peningkatan jumlah ammonia setelah penambahan daun Chromolaena odorata di dalam pakan komplit. Peningkatan kandungan ammonia disebabkan oleh kandungan protein pakan semakin tinggi dengan pemakaian Chromolaena odorata. Kandungan ammonia tertinggi dihasilkan perlakuan C yaitu $20,31 \mathrm{mg} / 100 \mathrm{ml}$ dan terendah perlakuan A yaitu $19,74 \mathrm{mg} / 100 \mathrm{ml}$. Kandungan ammonia yang tidak berbeda nyata disebabkan oleh pemanfaatan protein yang sesuai dengan kondisi pakan yang dimanfaatkan lebih efisien untuk sintesis protein mikroba. Produksi amonia tergantung pada kelarutan protein ransum, jumlah protein ransum, lamanya makanan berada dalam rumen dan $\mathrm{pH}$ rumen serta pemanfaatannya untuk sintesis protein mikroba (Ørskov, 1988). Sutardi (1980) menyatakan bahwa amonia dibutuhkan oleh sebagian besar 
Tabel 2. Hasil Pengukuran Variabel setelah 48 Jam Inkubasi secara In-vitro

\begin{tabular}{lccc}
\hline \multirow{2}{*}{ Variabel Diukur } & \multicolumn{3}{c}{ Perlakuan } \\
\cline { 2 - 4 } & A & B & C \\
\hline Produksi gas (ml) & $71,49^{\mathrm{b}}$ & $65,27^{\mathrm{a}}$ & $60,33^{\mathrm{a}}$ \\
Degradabilitas bahan kering (\%) & $61,38^{\mathrm{a}}$ & $63,42^{\mathrm{ab}}$ & $64,13^{\mathrm{b}}$ \\
Degradabilitas bahan organik (\%) & $61,64^{\mathrm{a}}$ & $62,12^{\mathrm{ab}}$ & $64,34^{\mathrm{b}}$ \\
Ammonia (mg/100 ml) & 19,74 & 19,94 & 20,31 \\
VFA Total (mM) & 121,70 & 112,30 & 108,90 \\
Biomassa mikroba (mg) & $107,05^{\mathrm{a}}$ & $114,21^{\mathrm{ab}}$ & $123,34^{\mathrm{b}}$ \\
Bahan Organik Tercerna (BOT) (mg) & $161,89^{\mathrm{a}}$ & $169,06^{\mathrm{ab}}$ & $173,51^{\mathrm{b}}$ \\
Effisiensi pembentukan mikroba (\% BOT) & 66,61 & 67,96 & 73,14 \\
\hline Ken
\end{tabular}

Keterangan $^{\mathrm{a}-\mathrm{b}}=$ Superskrip yang berbeda pada baris yang sama menunjukkan berbeda nyata $(\mathrm{P}<0,05)$

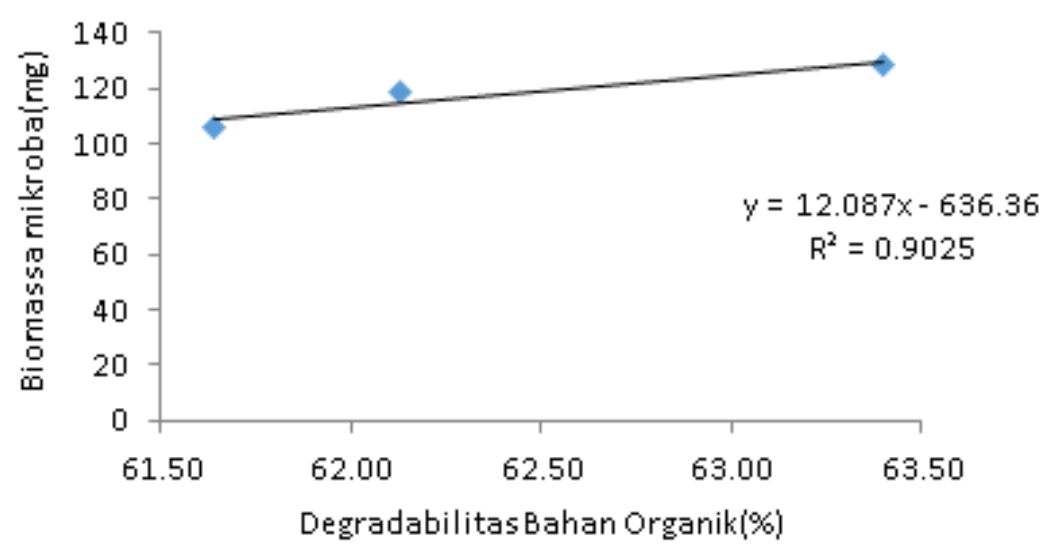

Gambar 2. Grafik Hubungan Linier antara DBO dengan Biomassa Mikroba

mikroba sebagai sumber $\mathrm{N}$, asam keto alfa dan VFA sebagai sumber kerangka karbon dan sumber energi untuk sintesis asam amino penyusun protein sel mikroba. Kandungan energi dan protein yang terdapat dalam bahan pakan dibutuhkan oleh mikroba rumen untuk sintesis protein mikroba sebagai sumber protein utama bagi ternak ruminansia $(\varnothing$ rskov dan Ryle , 1990).

Kandungan VFA total yang diperoleh tidak berbeda nyata diantara perlakuan $(\mathrm{P}>0,05)$ dimana VFA total tertinggi dihasilkan perlakuan A yaitu $121,7 \mathrm{mMol}$ dan terendah perlakuan C yaitu $108,9 \mathrm{mMol}$. Secara umum terlihat penurunan konsentrasi VFA setelah penambahan setelah penambahan daun Chromolaena odorata di dalam pakan komplit. Pemanfaatan VFA yang optimal dengan ketersediaan protein pakan yang cukup membuat kandungan VFA total perlakuan C menjadi paling rendah. Hungate (1966) menyatakan bahwa VFA merupakan produk akhir fermentasi karbohidrat dan merupakan sumber energi utama asal rumen. Kandungan VFA ini masih dalam batas konsentrasi normal VFA yaitu antara 70 sampai 150 mMol (Mc Donald, 2002), ini menggambarkan bahwa ketersediaan mikroba untuk mensintesis protein mikroba. Mikroba rumen mengubah asam organik menjadi VFA disertai dengan terbentuknya gas ( Ørskov dan Ryle, 1990). Konsentrasi VFA perlakuan sesuai dengan laju produksi gas yang terbentuk. Tingginya produksi gas merupakan indikator terbentuknya VFA terutama asam asetat dan propinat (Menke et al., 1979). 


\section{KESIMPULAN}

1. Penggunaan Chromolaena Odorata meningkatkan kandungan protein pakan lengkap.

2. Penggunaan Chromolaena Odorata sebanyak $40 \%$ secara signifikan $(\mathrm{P}<0,05)$ dapat meningkatkan degradabilitas bahan kering, bahan organik dan produksi biomassa mikroba dari $61,38 \% ; 61,64 \%$ dan 107,05 mg menjadi $64,13 \% ; 64,34 \%$ dan 123,34 mg secara berturut-turut.

3. Penggunaan Chromolaena Odorata secara nyata $(\mathrm{P}<0,05)$ menurunkan produksi gas yang dihasilkan selama 48 jam inkubasi dari 71,49 menjadi $60,33 \mathrm{ml} / 500 \mathrm{mg} \mathrm{BK}$.

4. Hasil terbaik diperoleh pada perlakuan $\mathrm{C}$ yaitu penggunaan $40 \%$ Chromolaena Odorata di dalam pakan lengkap.

\section{DAFTAR PUSTAKA}

Andini., L, Firsoni, dan C.E. Kusumaningrum. 2011., Nilai nutrisi pakan komplit berbasis jerami fermentasi untuk ruminansia secara in-vitro. Prosiding Seminar Nasional Teknologi Peternakan dan Veteriner. Bogor 7-8 Juni 2011 ISBN 978-602-8475-46-4

Blummel, M., H.P.S. Makkar and K. Becker. 1997. The in vitro gas production: A technique revisited. J, Anim. Phys. Nutr. 77: 24-34.

Czerkawski, J.W. 1986. An Introduction to Rumen Studies . 1 st . ed . Studies Pergamon Press . New York.

Ella, Hardjosoewignyo, T.R. Wiradaryawan dan M. Winudho. 1997. Perlakuan produksi gas dari hasil proses fermentasi beberapa jenis leguminosa pakan. Dalam : Seminar Nasional Ilmu-ilmu dan Makanan Ternak. Fakultas Peternakan Institut Pertanian Bogor dan Asosiasi Ilmu Nutrisi dan Makanan Ternak (AINI). Bogor. Indonesia.

Getachew, G., P.H. Robinson, E.J. DePeters. dan S.J. Taylor. 2004. Relationships between chemical composition, dry matter degradation and in vitro gas production of several ruminant feeds. Anim. Feed Sci. And Technol. 111:5771.

Ginting. Ng., Yuningsih dan Indraningsih. 1981. Tanaman beracun di daerah Jawa Barat. Bull. Lembaga Penelitian. Penyakit Hewan 21: 63 - 72.

Hungate, R.E.1996. The Rumen and its Mikrobes Academic Press, New York.

Ikhimiyoya, 2003. Acceptability of selected common shrubs/tree leaves in Nigeria by West African Dwarf Goats. Departement of Animal Science, Faculty of Agriculture, Ambrose Alli University, Ekpoma, Nigeria.

Krisnamooorty, U. 2001. RCA training workshop on in-vitro techniques for feed evaluation. The International Atomic Energy Agency, Vienna, Austria.pp. 826.

Makkar, H.P.S., M. Blummel and K. Becker. 1995. Formation of complexes between polyvinyl pyrolidones on polyethylene glycol and tannin and their implication in gas production and true digestibility. British J. of Nutr. 73 : 893-913

Marthen. L., 2007. Pemanfaatan semak bunga putih (Chromolena odorata) untuk peningkatan produksi tanaman dan ternak. Fakultas pertenakan universitas Nusa cendana,kupang, NTT.

McDonald, P., R.A. Edwards, J.F.D. Greenhalq. 2002. Animal Nutrition . 4th ed Longman Scientific and Tehnical, Hongkong.

Menke.K.H., L. Raab, A. Salewaki, H. Steingass, D. Fruitz dan W. Scihneider. 1979. Estimation of the digesbility and metabolizable energy content of ruminant feedstufft from gas production when they are incubated with rumen liquator in vitro. J. Agric . Sci. 93: 217 222. http://webcache.googleusercontent. $\mathrm{com} /$ search?q=8mLoMI9uicJ:ejournal 
.umm.ac.id. (diakses 16 Januari 2013 pukul 11.56 WIB).

Ørskov, E.R, dan M. Ryle. 1990. Energy Nutrition in Ruminant. London: Elseivier.

$\varnothing$ rskov. 1988. Protein Nutrition in Ruminants. 2nd Edition. Academic Press Limited. London.

Sipayung, A., R.D. De Chenon dan P.S. Sudharto. 1991. Observations on Chromolaena odorata (L.) R.M. King and H. Robinson in Indonesia. Second International Workshop on the Biological Control and Management of Chromolaena odorata. Biotrop, Bogor. http://www.ehs.cdu.edu.au/chromolaena /2/2sipay. ( Diakses 13 Januari 2013).

Sutardi, T. 1980. Landasan nutrisi. Jilid I. Dep. Ilmu Makanan Ternak. Fakultas Peternakan. IPB. Bogor 